\title{
Impact of field roughness and power losses, turbulence intensity on electricity production for an onshore wind farm
}

\author{
Bedri Dragusha, Bukurije Hoxha \\ Faculty of Mechanical Engineering, Department of Thermoenergetics and Renewable Energy, University of Prishtina, \\ Kosovo
}

\begin{tabular}{|c|c|}
\hline Article Info & ABSTRACT \\
\hline Article history: & \multirow{9}{*}{$\begin{array}{l}\text { When designing a power generation project from a different source, and in } \\
\text { our case study, wind, when calculating the annual energy produced, it is } \\
\text { necessary to define and calculate the losses incurred in the system. The main } \\
\text { cause of losses in a wind park is due to the oscillations caused by the } \\
\text { turbulence of the air around the turbine because of roughness of terrain. The } \\
\text { paper describes two methods of estimating turbulence intensity: one based on } \\
\text { the mean and standard deviation (SD) of wind speed from the nacelle } \\
\text { anemometer, the other from mean power output and its SD. These analyses } \\
\text { are very important for understanding the fatigue and mechanical stress on the } \\
\text { wind turbines. Then significance of the site ruggedness index (RIX) and the } \\
\text { associated performance indicator ( } \Delta \text { RIX) are confirmed for terrain and the } \\
\text { consequences of applying WAsP outside its operating envelope are } \\
\text { quantified. }\end{array}$} \\
\hline Received Dec 18, 2019 & \\
\hline Revised Mar 14, 2020 & \\
\hline Accepted Apr 13, 2020 & \\
\hline Keywords: & \\
\hline Wind energy & \\
\hline Wind simulations & \\
\hline $\begin{array}{l}\text { Energy production } \\
\text { Efficiency }\end{array}$ & \\
\hline & \\
\hline
\end{tabular}

Wake losses

Turbulence

This is an open access article under the CC BY-SA license.

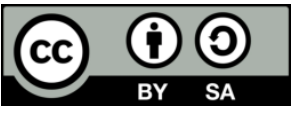

\section{Corresponding Author:}

Bukurije Hoxha,

Faculty of Mechanical Engineering,

Department of Thermoenergetics and Renewable Energy, University of Prishtina, Kosovo

Email: bukurije.hoxha@uni-pr.edu

\section{INTRODUCTION}

The structure, operation, and planning of electric power networks will undergo considerable and rapid changes due to increased global energy consumption. Therefore, electric utility companies are striving to install wind turbines as energy resources to meet growing customer load demand [1, 2]. The mechanical energy from wind after getting converted into electrical energy through turbine and generator, enters into the collector system of the wind farm [3]. Wind turbine technology has undergone a revolution during the last century $[4,5]$. Because of excessive investment, climate limitations, and maintenance difficulties of offshore wind farms compared to onshore wind farms, onshore wind farms are also attracting increasing attention from wind power companies [6]. More fundamentally, understanding and reliably predicting wind dynamics remains a central problem in order to forecast wind power [7]. Turbulence in the wind is caused by dissipation of the wind's kinetic energy into thermal energy through the creation and destruction of progressively smaller eddies $[8,9]$. To calculate the amount of energy obtained from a turbine located at the aforementioned location, the analytical path is used, recognizing the strength of the wind and the mechanical strength obtained from it $[10,11]$. More fundamentally, understanding and reliably predicting wind dynamics remains a central problem in order to forecast wind power [12]. The ruggedness index concept has been used extensively over the last 10 years in wind resource assessment and siting studies in complex terrain, especially in terrain, which is outside the operational envelope of linearised flow models such as WAsP [13]. Kosovo as a signatory of the Energy Community Treaty plans the construction and use of renewable energy capacities in the value of $20 \%$. One of the ways of using renewable energy in Kosovo is the use of wind 
power [14]. Site ruggedness index calculations have now been implemented in the WAsP program for all predictor and predicted sites [15]. The major goal of Optimal Power Flow (OPF) is to improve a target capacity such as cost of fuel by means of ideal change of the control variables simultaneously different equality and inequality constraints $[16,17]$.

Wind and other meteorological measurements with a met mast on site starting from August 2017 to December 2017 are made for Kitka Wind Park in Kamenica. This farm is located at about 7km north of Kamenica city of Kosovo, which is at the eastern part of Kosovo.

Based on the correlation coefficient and concurrent measurement period of datasets, 30 - year time series have been synthesized. Regarding uncertainties were taken into account in analysis.

It is noted that measurement period covers only 3.5 months and average wind speed is affected by seasonal variations. As measurement period is coinciding with low wind, season $6 \%$ increase in average wind speed is compatible with long-term data trends. First, we will investigate to what extent the site ruggedness index and orographic performance indicator concepts are still supported when using contemporary calculation procedures and topographic data. The study of the field roughness index was done using WAsP software.

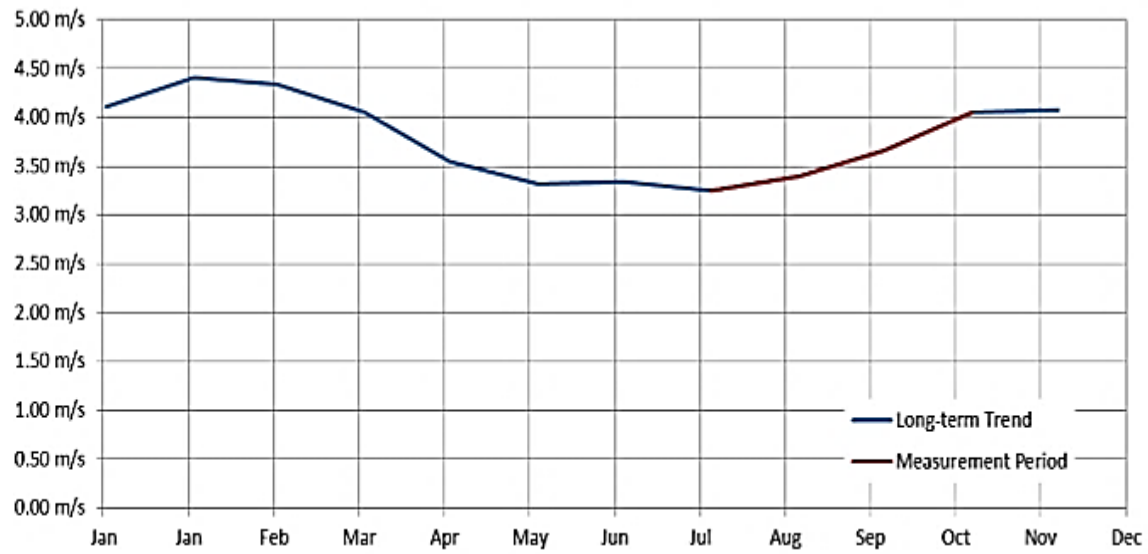

Figure 1. Long-term monthly wind speed trends (reference time series)

Table 1. Comparison of wind data measurement

\begin{tabular}{cccc}
\hline Long-term Measurement Source & $\begin{array}{c}\text { Correlation Coefficient R } \\
\text { (Weekly Average) }\end{array}$ & Period & $\begin{array}{c}\text { Wind Speed } \\
\text { Adjustment }\end{array}$ \\
\hline MERRA-2 Reanalysis Data & 0.221 & $01.01 .1995-21.10 .2017$ & - \\
MERRA-2 Raw Reanalysis Data & 0.694 & $01.01 .1987-30.11 .2017$ & $105.99 \%$ \\
NCAR - CFSR Reanalysis Series & 0.258 & $01.01 .2011-30.11 .2017$ & - \\
\hline
\end{tabular}

\section{METHOD OF STUDY}

The site consists of agricultural land, short shrubs and forest areas. Most of the wooded areas are on the northern hillside of the site. Wooded areas are showing similar characteristic of about $10 \mathrm{~m}$ height and closed formation. General Electric 3.6MW and General Electric 3.2MW turbines are studied for the site. Turbines characteristics are given in below table.

Table 2. Technical characteristics of wind turbines taken in study

\begin{tabular}{ccc}
\hline Variables & General Electric 3.2MW & General Electric 3.6MW \\
\hline Power & $3200 \mathrm{KW}$ & $3600 \mathrm{KW}$ \\
Hub Height & $110 \mathrm{~m}$ & $110 \mathrm{~m}$ \\
Rotor Diameter & $130 \mathrm{~m}$ & $137 \mathrm{~m}$ \\
Sweeping Area & $53,093 \mathrm{~m}^{2}$ & $58,965 \mathrm{~m}^{2}$ \\
Tower & Tubular & Tubular \\
Grid connection & $50 / 60 \mathrm{~Hz}$ & $50 / 60 \mathrm{~Hz}$ \\
IEC Class & IIB (Medium TI) & IIIC $(\mathrm{Low} \mathrm{TI})$ \\
Power Curve Air Density & $1.225 \mathrm{~kg} / \mathrm{m} 3$ & $1.225 \mathrm{~kg} / \mathrm{m} 3$ \\
\hline
\end{tabular}



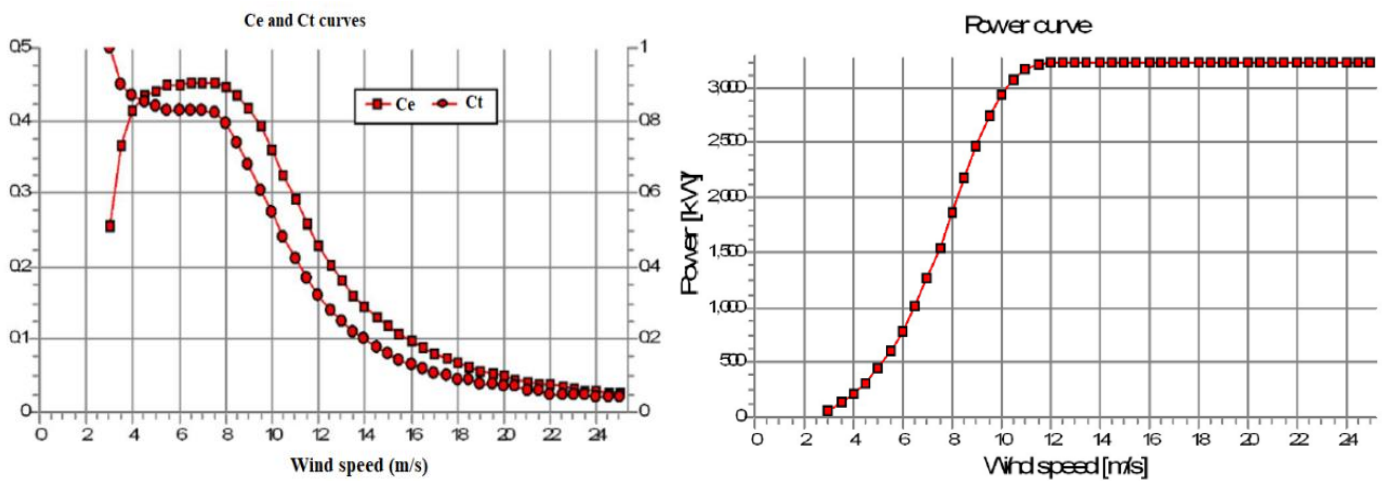

Figure 2. $\mathrm{C}_{\mathrm{e}}$ and $\mathrm{C}_{\mathrm{t}}$ curves for GE wind turbines, and power curve based on wind speed

Turbulence intensity (TI) is one of the variables to estimate fatigue loads on the turbine components. It is defined as the ratio of the wind speed standard deviation to the wind speed. As the result of expected wind speed increase due to boundary layer wind shear characteristic of the wind, a proportional decrease in turbulence intensity is also expected at upper heights, as in Figure 3 is shown. IEC propose a method to define turbine class according to turbulence intensity at $15 \mathrm{~m} / \mathrm{s}$ wind speed. Average ambient turbulence intensity at met mast location at hub height is obtained as follows.

\begin{tabular}{ccc}
\hline Met Mast Location at Hub Height & Ambient Turbulence Intensity & Ambient TI 1.28SD \\
\hline $110 \mathrm{~m}$ & $9 \%$ & $12 \%$ \\
\hline
\end{tabular}

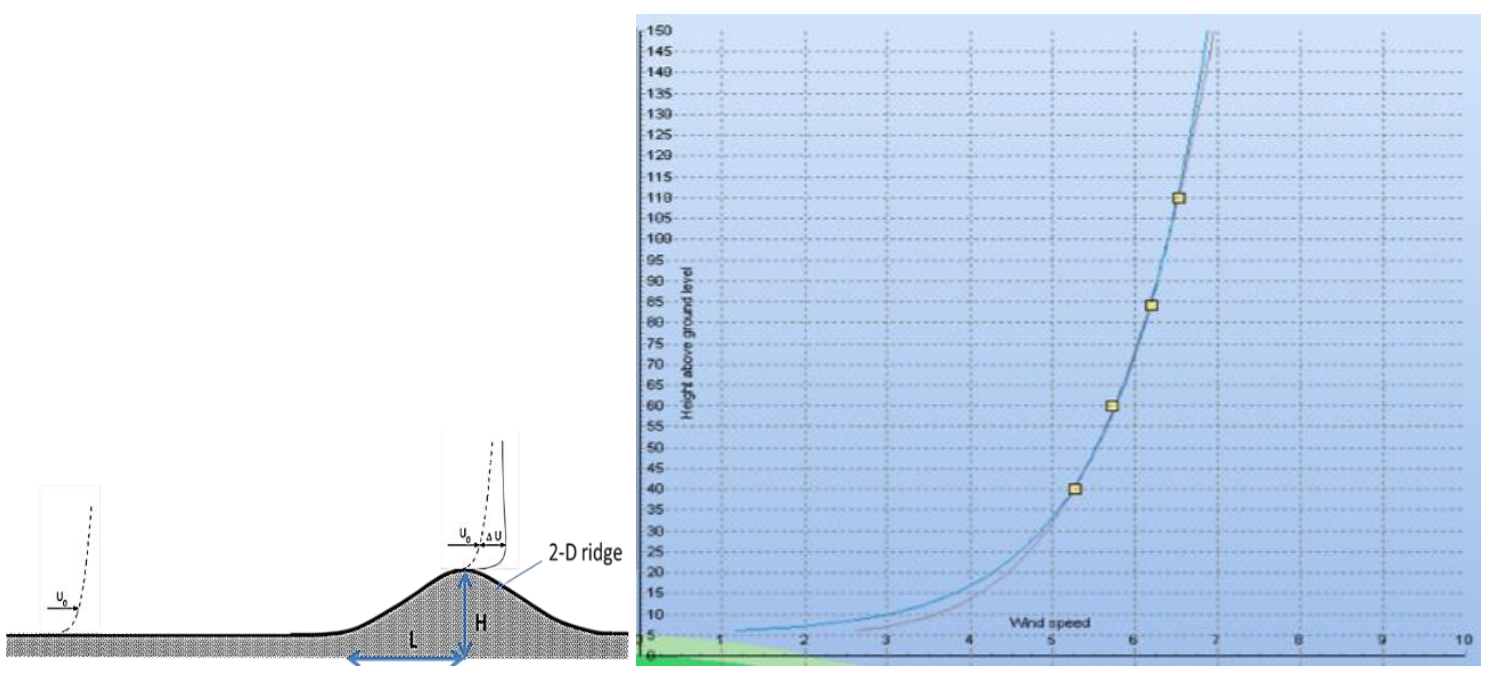

Figure 3. Changing of wind speed by altitude in study terrain, Kitka

Onshore wind farms: Wind turbines sitting over complex terrains, Atmospheric stability is rarely close to near neutral (highly convective - unstable during the day time and highly stable nocturnal conditions with high shear at night time), much higher ambient turbulence level [18, 19]. The surface flow characteristics are highly dependent on the slope of the hill [20, 21].

Wake effects have been calculated by N.O Jensen Wake model. Park efficiency of $95.4 \%$ is achieved. Turbines are not observed to be aligned in prevailing wind direction and in non-prevailing wind direction horizontal distances are considered suitable. 


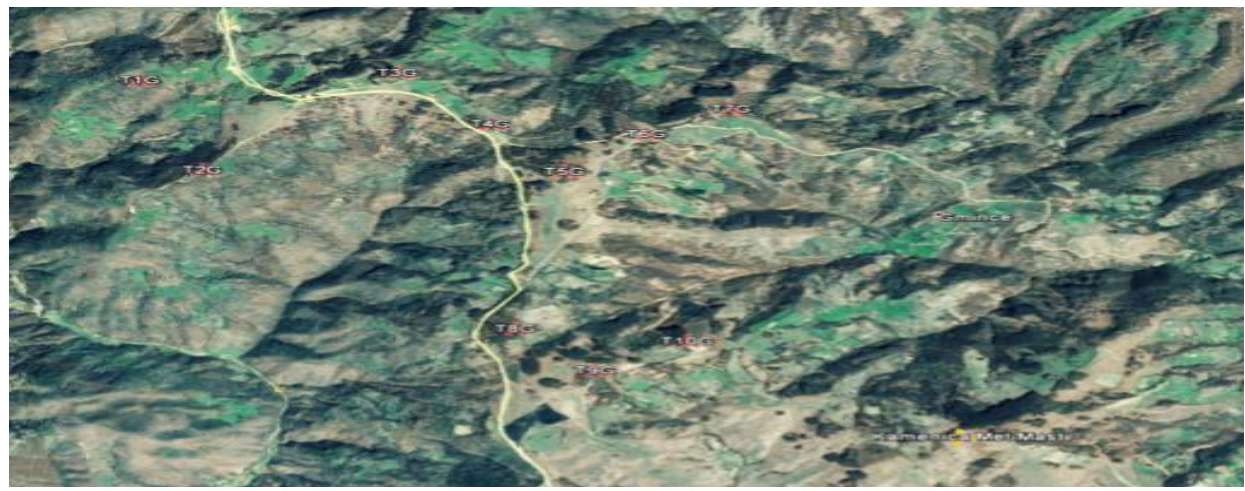

Figure 4. Placement of wind turbines
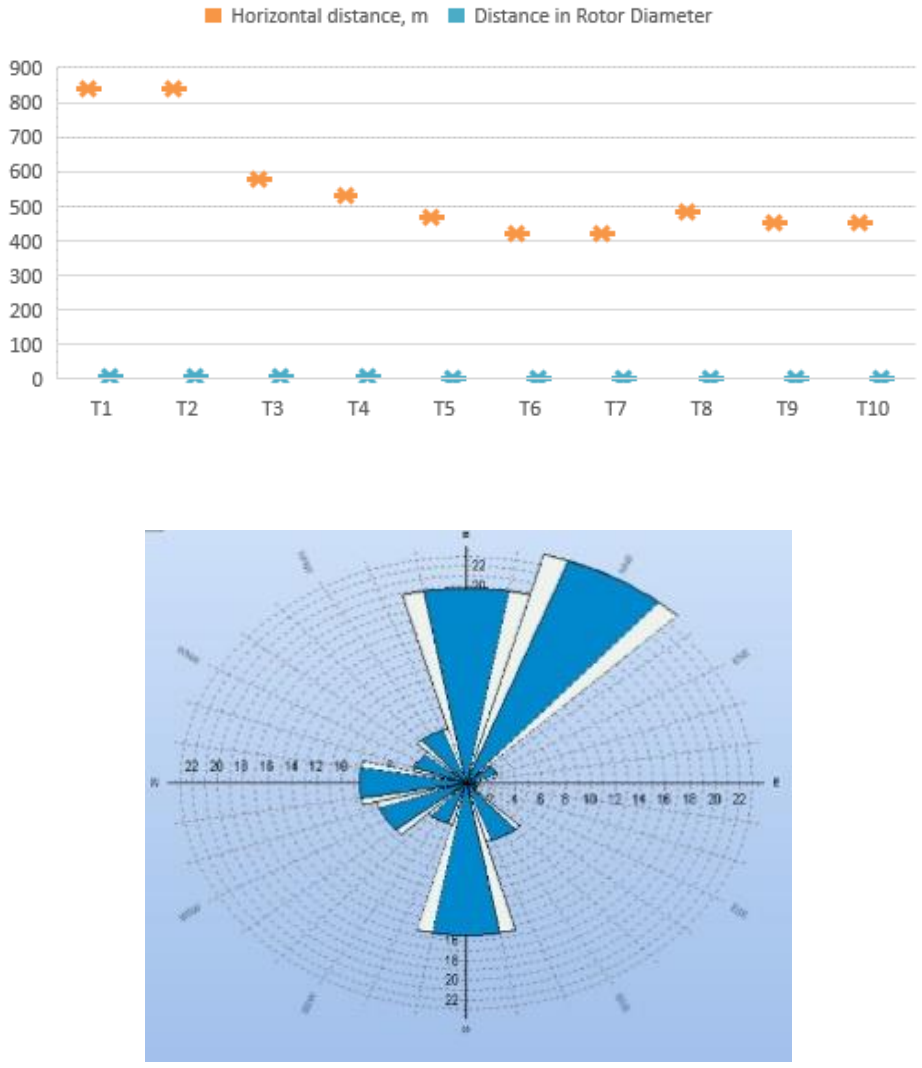

Figure 5. Wind farm turbines layout and Kitka wind rose

\section{RESULTS AND DISCUSSIONS}

Vertical extrapolation uncertainty is resulted from two different sources. Difference between measurement height and hub height is one of them and considered as $0.7 \%$ per $10 \mathrm{~m}$ difference in accordance with the complexity of the site. The other source of uncertainty is the difference between elevation of the met mast and the turbines, which is considered $0.7 \%$ per $10 \mathrm{~m}$ elevation difference for the site. Resulting wind speed and annual energy production uncertainties for each turbine is presented below. Due to the high elevation differences between met mast and the turbine T1G higher AEP uncertainty is expected. CFD analysis of the site will substantially reduce these uncertainties. The sensitivity of the flow field to the terrain description has direct consequences for numerical modelling, which is the preferred tool for estimating how the terrain affects wind resources at wind-turbine sites [22, 23]. 
Table 3. Wind turbines delta elevation and delta height with annual energy production

\begin{tabular}{ccccc}
\hline WTG & Delta elevation & Delta height & Result, wind speed $\mathrm{m} / \mathrm{s}$ & Result, AEP \% \\
\hline T1 & $-93.4 \mathrm{~m}$ & $26 \mathrm{~m}$ & 6.8 & 12.4 \\
T2 & $-60.0 \mathrm{~m}$ & $26 \mathrm{~m}$ & 4.6 & 8.5 \\
T3 & $-20.2 \mathrm{~m}$ & $26 \mathrm{~m}$ & 2.3 & 4.1 \\
T4 & $-40.1 \mathrm{~m}$ & $26 \mathrm{~m}$ & 3.3 & 5.8 \\
T5 & $-30.0 \mathrm{~m}$ & $26 \mathrm{~m}$ & 2.8 & 4.9 \\
T6 & $-0.0 \mathrm{~m}$ & $26 \mathrm{~m}$ & 1.8 & 3.2 \\
T7 & $-28.2 \mathrm{~m}$ & $26 \mathrm{~m}$ & 2.7 & 4.9 \\
T8 & $10.0 \mathrm{~m}$ & $26 \mathrm{~m}$ & 1.9 & 3.5 \\
T9 & $20 \mathrm{~m}$ & $26 \mathrm{~m}$ & 2.3 & 4.0 \\
T10 & $-20 \mathrm{~m}$ & $26 \mathrm{~m}$ & 2.3 & 4.2 \\
& & Total & & 5.6 \\
\hline
\end{tabular}

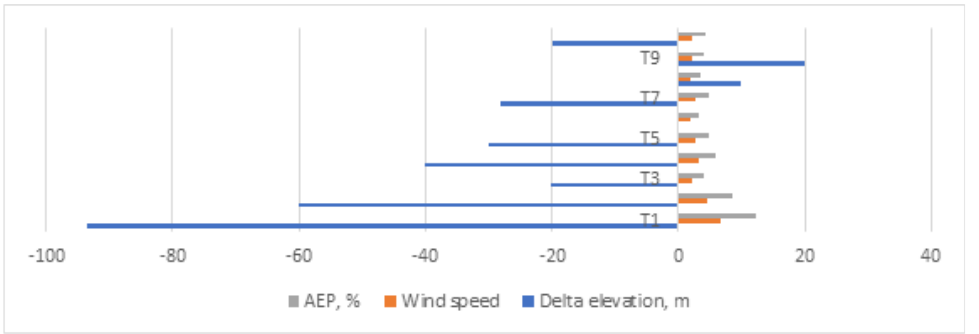

Figure 6. Annual energy production from wind turbines in Kitka, based on delta elevation of their placement

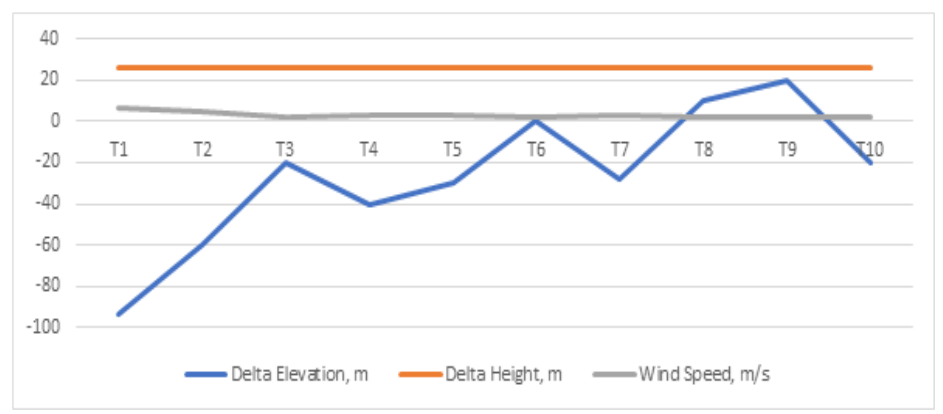

Figure 7. Comparison between delta elevation and delta height of wind turbines and wind speed on them

The characteristics of the turbines obtained in the study, together with the test conditions under which the test characteristics for the respective power result, are given below.

Table 4: Technical characteristics of two wind turbine models

\begin{tabular}{cc}
\hline Turbine type & $7 \times$ GE $3.6-137$ \\
& $3 \times$ GE 3.2-130 \\
\hline Hub height & $110 \mathrm{~m}$ \\
Rated power & $3600 \mathrm{~kW} \mathrm{\&} 3200 \mathrm{~kW}$ \\
Number of turbines & 10 \\
Installed capacity & $34.8 \mathrm{MW}$ \\
\hline
\end{tabular}

Table 5. Annual energy production from wind farm

\begin{tabular}{cc}
\hline Expected lifetime of WTG & 20 years \\
\hline Gross annual energy production & $122,883 \mathrm{MWh}$ \\
Wake effects & $95.4 \%$ \\
Availability & $96.3 \%$ \\
Turbine Performance & $99.7 \%$ \\
Electrical losses & $98.0 \%$ \\
Environmental losses & $98.5 \%$ \\
Curtailment losses & $100.0 \%$ \\
Total Losses & $88.4 \%$ \\
\hline
\end{tabular}

Impact of field roughness and power losses, turbulence intensity on electricity ... (Bedri Dragusha) 
Tables 6 and 7, shows the results of calculations of the mean value of turbulence intensity at different measuring heights during the one-year measurement period. Only ten-minute intervals were considered where the wind speed was higher than $3 \mathrm{~m} / \mathrm{s}$.

Table 6. Average value of wind turbulence intensity in Koznica wind park, for different measuring heights,

\begin{tabular}{cccc}
\multicolumn{4}{c}{ during the measurement period during one year $(\mathrm{w} \geq 3 \mathrm{~m} / \mathrm{s})$} \\
\hline Height of measurement & $84 \mathrm{~m}$ & $60 \mathrm{~m}$ & $40 \mathrm{~m}$ \\
\hline $\mathrm{TI}(\mathrm{w}=3 \mathrm{~m} / \mathrm{s})(\%)$ & 10.5 & 10.9 & 11.4 \\
\hline
\end{tabular}

Table 7. Average value of wind turbulence intensity in Koznica wind park, for different measuring heights, during the measurement period during one year $(\mathrm{w} \geq 15 \mathrm{~m} / \mathrm{s})$

\begin{tabular}{cccc}
\hline Height of measurement & $84 \mathrm{~m}$ & $60 \mathrm{~m}$ & $40 \mathrm{~m}$ \\
\hline $\mathrm{TI}(\mathrm{w}=15 \mathrm{~m} / \mathrm{s})(\%)$ & 13.79 & 14.3 & 14.34 \\
\hline
\end{tabular}

It is extremely valuable - and sometimes required for bankable estimates - to install two or more masts at the wind farm site; cross-prediction between such masts will provide assessments of the accuracy and uncertainty of the flow modelling over the site. Two or more masts are also required in complex terrain, where ruggedness index (RIX) and $\Delta$ RIX analyses are necessary, as in figures 8 and 9, where RIX characteristic is a very important point $[24,25]$.

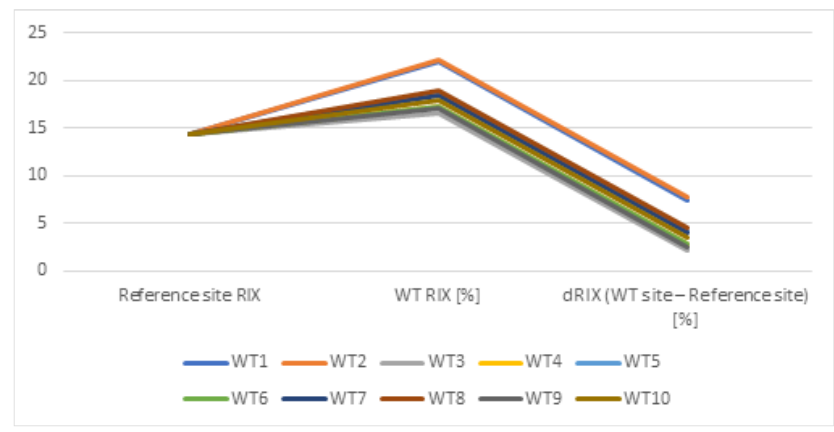

Figure 8. Reference site and WT RIX, and difference between them

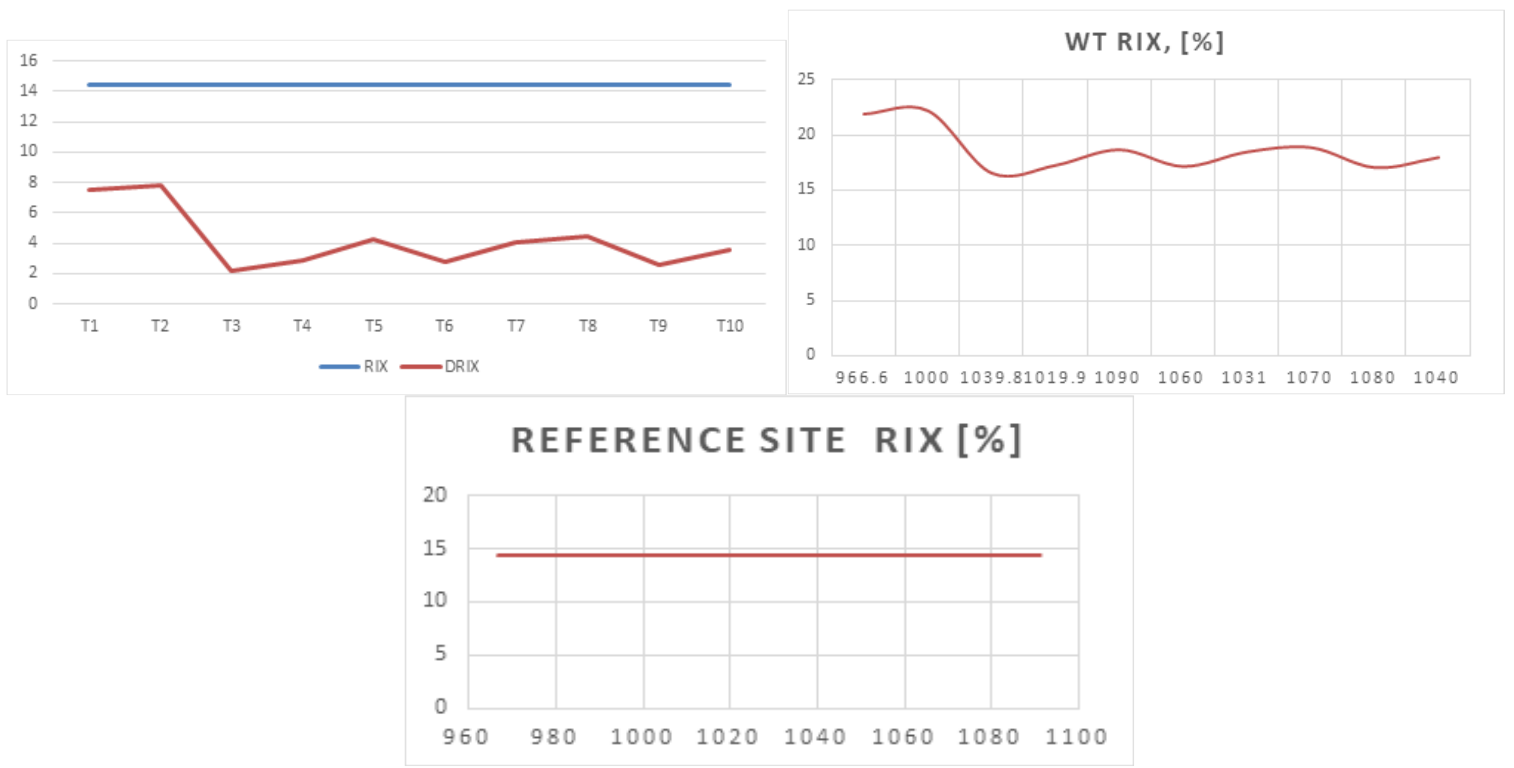

Figure 9. Comparison of reference site roughness based on wind turbine number and based on their elevation 
As expected in this case, from the figures presented in Figure 9, the roughness of the terrain is unchanged and less than that of the wind turbines, while the dRIX in the wind turbines increases this value because of additional turbulence created in them.

\section{CONCLUSIONS}

Kitka has a moderate wind resource for wind power development. Wind behavior at the met tower sites demonstrates low extreme wind probability but moderately high-to-high turbulence due to heavy brush to the north. From the above analysis it can be clearly seen how the relationship between RIX of site and RIX of wind turbines. The roughness index for the case of the ground surface where the wind turbines are located is constant no matter how the altitude of the terrain changes where they are located within the wind park. As $\triangle$ RIX values between met mast and turbine locations are in the range of $2.2 \%$ and $7.8 \%$, similarity principle can be said to be mostly achieved. Since the degree of roughness of the turbines depending on the terrain where they are to be located is within the accepted range then it follows that similar turbines can be installed in Kitke without prejudice to the quality of energy that can be produced.

\section{REFERENCES}

[1] Ahmed Al Ameri, Aouchenni Ounissa, Cristian Nichita Aouzellag Djamal "Power Loss Analysis for Wind Power Grid Integration Based on Weibull Distribution”, Energies, vol. 10, no. 4, pp. 463-479, 2017.

[2] M. Pushpavalli, N. M Jothi Swaroopan, "Performance analysis of hybrid photovoltaic/wind energy system using KY boost converter", International Journal of Power Electronics and Drive System (IJPEDS), vol. 10, no. 1. pp. 433-443, 2019.

[3] Akhilesh Prakash Gupta, Student Member, A. Mohapatra, and S. N. Singh, "Apparent Power Loss Based Equivalent Model of Wind Farm Collector System", Proceedings of the National Power Systems Conference (NPSC), NIT Tiruchirappalli, India, December 14-16, 2018.

[4] Z. Chen, "Issues of Connecting Wind Farms into Power Systems", IEEE/PES Transmission and Distribution Conference \& Exhibition: Asia and Pacific Dalian, China, 2005.

[5] Benouaz Idriss Yassine, Allaoua Boumediene, "Renewable energies evaluation and linking to smart grid", International Journal of Power Electronics and Drive Systems (IJPEDS), vol. 11, no. 1, pp. 107-118, 2020.

[6] Xiawei Wu, Weihao Hu, Qi Huang, Cong Chen, Zhe Chen, Frede Blaabjerg, "Optimized Placement of Onshore Wind Farms Considering Topography”, Energies, Vol. 12, pp. 2944, 2019.

[7] Patrick Milan, Matthias Wa"chter, and Joachim Peinke, "Turbulent Character of Wind Energy", Physical Review Letters, vol. 110, 2013.

[8] Kristine Mikkelsen, "Effect of free stream turbulence on wind turbine performance", Norwegian University of Science and Technology, 2013.

[9] Bukurije Hoxha, Bedri Dragusha, "Wind Energy Prediction in Kosovo by WAsP11 software", Przeglad Elektrotechniczny, vol. 1, no. 3, pp. 127-130, 2020.

[10] Sabrije OSMANAJ, Bukurie HOXHA, Rexhep SELIMAJ, “An experimental study of Wind Data of a Wind Farm in Kosovo", Przegląd Elektrotechniczny Vol. 1, No, 7, pp. 23-27, 2013.

[11] Mohamed Nadour, Ahmed Essadki, Tamou Nasser, Mohammed Fdaili, "Robust coordinated control using backstepping of flywheel energy storage system and DFIG for power smoothing in wind power plants", International Journal of Power Electronics and Drive System (IJPEDS), vol. 10, no. 2. pp. 1110-1122, 2019.

[12] I. Van der Hoven, "Power Spectrum of Horizontal Wind Speed in The Frequencyrange from 0.0007 To 900 Cycles Per Hour" Journal of Meteorology, vol. 14 160-164, 1957

[13] Firas A. Hadi, Samah Shyaa Oudah, Rafa A. Al-Baldawi, "Pre-feasibility Study of Hypothetical Wind Energy Project Using Simulated and Measured Data", 2nd International Conference for Engineering, Technology and Science of Al-Kitab University, 2018.

[14] Bukurije Hoxha, Rexhep Selimaj, Sabrije Osmanaj, “An Experimental Study of Weibull and Rayleigh Distribution Functions of Wind Speeds in Kosovo", TELKOMNIKA (Telecommunication, Computing, Electronics and Control), vol.16, no.5, pp. 2451-2457, 2018.

[15] Rathmann, O., N.G. Mortensen, L. Landberg and A. Bowen, "Assessing the accuracy of WAsP in non-simple terrain”, Proceedings of the 18th British Wind Energy Association Conference, Wind Energy Conversion, pp. 413418, 1996.

[16] P. Nagaleshmi, "Solution for optimal power flow problem in wind energy system using hybrid multi objective artificial physical optimization algorithm", International Journal of Power Electronics and Drive System (IJPEDS), vol. 10, no. 1, pp. 486-503, 2019.

[17] Wei Tian, Ahmet Ozbay, Wei Yuan, Partha Sarakar, Hui Hu, "An Experimental Study on the Performances of Wind Turbines over Complex Terrain", 51st AIAA Aerospace Sciences Meeting including the New Horizons Forum and Aerospace Exposition, 2013.

[18] Ahmet Ozbay, Wei Tian, Hui Hu, "An Experimental Study on the Effects of Wake Interference on the Performance of Wind Turbines over Flat and Complex Terrains", Iowa State University, Educational Resources on Wind Energy, 2013. 
[19] Wei Tiana, Ahmet Ozbay, Hui Hub, "Terrain effects on characteristics of surface wind and wind turbine wakes", Procedia Engineering, Vol. 126, pp. 542-548, 2015.

[20] Jihane Kartite, Mohamed Cherkaoui, "Improved backtracking search optimization algorithm for PV/Wind/FC system”, TELKOMNIKA (Telecommunication, Computing, Electronics and Control), Vol. 18, No. 1, pp. 456-464, 2020.

[21] Julia Lange, Jakob Mann, Jacob Berg, Dan Parvu, Ryan Kilpatrick, Adrian Costache, Jubayer Chowdhury, Kamran Siddiqui, Horia Hangan "For wind turbines in complex terrain, the devil is in the detail", Environmental Research Letters, Vol. 12, 2017.

[22] Leandro Jose Lemes Stival, Alexandre Kolodynskie Guetter, Fernando Oliveira de Andrade, "The impact of wind shear and turbulence intensity on wind turbine power performance", Espaço Energia, 2017.

[23] Niels G. Mortensen, "Planning and Development of Wind Farms: Wind Resource Assessment and Siting", DTU Wind Energy, 2013

[24] Himani, Navneet Sharma, "Hardware-in-the-loop simulator of wind turbine emulator using labview", International Journal of Power Electronics and Drive System (IJPEDS), vol. 10, no. 2. pp. 971-986, 2019.

[25] Warit Werapun, Yutthana Tirawanichakul, Jompob Waewsak, "Wind Shear Coefficients and their Effect on Energy Production”, Energy Procedia, Vol. 138, pp. 1061-1066, 2017. 